\title{
O imaginário do espaço no fotojornalismo on-line
}

Ana Taís Martins Portanova Barros

Anelise Angeli De Carli

Resumo: O artigo examina se e como o imaginário das marcas territoriais emerge no fotojornalismo quando as redes de comunicação expandem os espaços nacionais para além de seus limites geográficos. O material de análise é constituído por fotografias de capa dos jornais on-line mais acessados de cada continente. Utilizam-se as noções de imaginário (THOMAS), imagem simbólica e regimes do imaginário (DURAND), bem como as considerações de Bachelard sobre o imaginário do espaço. Conclui-se que o fotojornalismo achata o imaginário do espaço sob um imaginário territorial e sua eficácia simbólica não é proporcional à multiplicação de fotografias.

Palavras-chave: fotojornalismo; estudos do imaginário; espaço, território.

Abstract: The imaginary of the space in online photojournalism - This paper examines whether and how the imaginary of territorial marks emerges in photojournalism when communication networks expand domestic spaces for beyond their geographic boundaries. The material for analysis consists of photographic covers from the most accessed online newspapers from each continent. We adopt the notions of imaginary (Thomas), symbolic image and the imaginary schemes (Durand), as well as Bachelard's configurations on the imaginary of the space. We conclude that photojournalism flattens the imaginary of the space under a territorial imaginary and its symbolic efficacy is not proportional to the multiplication of photographs.

Keywords: photojournalism; imaginary studies; space; territory.

\section{Introdução}

O que o fotojornalismo contemporâneo nos conta sobre territórios e espaços? O fotojornalismo estaria hoje expressando uma homogeneização cultural colocada em curso pela globalização? 
Ao se distinguir de outros discursos visuais por sua forte ancoragem no real, a fotografia jornalística se colocaria como testemunha da história. O fotojornalismo depende de escolhas técnicas e estéticas marcadas por subjetividades: é resultado de um amálgama de motivações tais como competências técnicas do fotógrafo e sua mundivisão, bagagem cultural e expectativas em relação à receptividade da foto. Interessa-nos, porém, não a discussão acerca da subjetividade fotográfica, mas a manifestação no fotojornalismo de certo imaginário que traduz, por um lado, o sentimento ligado ao território que, no dizer de Santos (2003, p. 47), é “[...] o chão e mais a população, isto é uma identidade, o fato e o sentimento de pertencer àquilo que nos pertence. O território é a base do trabalho, da residência, das trocas materiais e espirituais [...]". O imaginário do território, pedaço de chão utilizado pelas populações, é o que transparece no nível fenomenológico das imagens, aquele que poderia ser designado como visível a olho nu, diferentemente do arquetipológico, como detalharemos adiante. Arquetipologicamente, não temos um território e sim um espaço que, embora mantendo com o território conexão estreita e mesmo relações de reversibilidade, é transcendental, cosmológico.

Nosso corpus empírico é constituído por fotografias de capa dos jornais on-line mais acessados de cada continente, segundo o ranking 2013, realizado pela empresa Media \& Newspapers. ${ }^{1}$ Escolhemos os jornais mais populares a fim de observar o comportamento do imaginário do espaço e do território no Oriente e no Ocidente. Tomamos o modelo de seis continentes tradicionais, considerando-se América do Norte e América do Sul como continentes diferentes. ${ }^{2}$ As fotografias foram destaque dos jornais na mesma data, 27 de dezembro de 2013. Nos casos de slideshow, capturamos aleatoriamente a fotografia que se apresentou no momento em que abrimos a página, de maneira a aproximar a mostração deste trabalho à experiência randômica do leitor.

Compreendendo, com Thomas (1998), o imaginário como um sistema dinâmico de imagens simbólicas, levamos em conta não só a fotografia, mas também o título que a ela se refere e sua relação com eventuais outras fotos que apareçam no mesmo campo de visão. Essa preocupação é metodológica e heurística, pois uma imagem isolada nunca é simbólica pelo simples motivo de não ser possível dirigir-lhe uma hermenêutica, já que o caráter simbólico se revela quando entra em homologia com outras imagens simbólicas (DURAND, 1997, p. 43). Uma imagem isolada no máximo pode ser lida no nível fenomênico, como uma possibilidade de símbolo degradado, já que estaria destituído da pregnância que pode ser conferida somente pela constelação de imagens.

Ao dizermos fenomenológico e arquetipológico, estamos nos referindo aos diferentes níveis de manifestação do imaginário. Verificou-se, com Durand (ibid., p. 443), que,

1 Segundo o site da empresa, a lista é baseada em algoritmo com métricas independentes de três motores de busca: Google Page Rank, Alexa Traffic Rank e Majestic Seo Referindo Domínios. Disponível em: <http://www.4imn. com>. Acesso em: 23 maio 2013.

2 Não analisamos a Antártida por não ser permanentemente habitada, não possuir habitantes nativos e não pertencer a nenhum país. 
de pregnantes no nível arquetipológico, as imagens passam por processos de restrição simbólica, indo dos arquétipos epítetos aos substantivos e chegando aos sintemas, sintomas sociológicos do símbolo, visíveis a olho nu - bem menos férteis embora muito mais numerosos. Enquanto os arquétipos habitariam o subsolo do imaginário, constituindo suas raízes, os sintemas se encontrariam num nível fenomênico, constituindo sua arborescência mais superficial, conforme a metáfora da árvore de imagens de Wunenburger (2002, p. 15). Assim, o imaginário pode trazer nas suas manifestações tanto marcas dessas raízes profundas, arquetipológicas, quanto de suas florações externas, fenomenológicas, tais como os sintemas.

Por essa diferenciação entre arquetipologia e fenomenologia do imaginário, a metodologia de análise conta com duas aproximações hermenêuticas. A primeira busca a fenotipia do imaginário da identidade nas marcas territoriais, considerando, quando pertinente, os níveis de codificação da mensagem visual arrolados por Eco (1976, p.162), a saber: icônico (qualidade colocada em relevo pela imagem), iconográfico (significado convencionado para a imagem), tropológico (figuras de linguagem traduzidas visualmente), tópico (bloco de opiniões pré-adquiridas e evocadas pelos iconogramas) e entimemático (argumentação ancorada no discurso verbal ou na interação do registro verbal com o visual).

Esses níveis de codificação não serão explorados um a um em todas as fotografias, mas apenas quando nos parecerem esclarecedores quanto ao objetivo de compreender a percepção do território favorecida pela imagem. Essa decupagem não nos coloca, ainda, em contato com a imagem simbólica; é necessária uma investigação capaz de reconduzir essa fenotipia a uma arquetipia.

Para tanto, lançamos mão da poética do espaço de Bachelard (1993) e da isotopia das imagens de Durand (1997, p. 441). Significa que consideramos o espaço enquanto reversível entre micro e macrocosmos, um habitat humano também em sua dimensão transcendental, com não separação entre o imanente e o transcendente.

Utilizamos apenas a título de informação descrições dos continentes apresentadas pela versão brasileira da Wikipedia por ser esta enciclopédia escrita por colaboradores voluntários, potencialmente não especialistas, o que acentua a probabilidade de as descrições corresponderem a uma espécie de senso comum sobre o tema, cristalizando os sintomas sociológicos das imagens simbólicas envolvidas.

\section{África olha para a Ásia}

O jornal on-line mais acessado da África é o Al-Ahram, sediado no Egito. A capa apresenta as fotos das principais notícias do dia em slideshow. Ao abrirmos a página, a fotografia que se apresentou foi a de uma manifestação na Turquia pela renúncia do primeiro-ministro Recep Tayyip Erdogan, cujo governo foi acusado de corrupção. ${ }^{3}$

3 Agradecemos a Faezeh Mohebi (Euronews e Université de Lyon III) e a Tariq Saleh (BBC World Service) pela colaboração para a compreensão dos textos e contextos das línguas árabe e chinesa. 


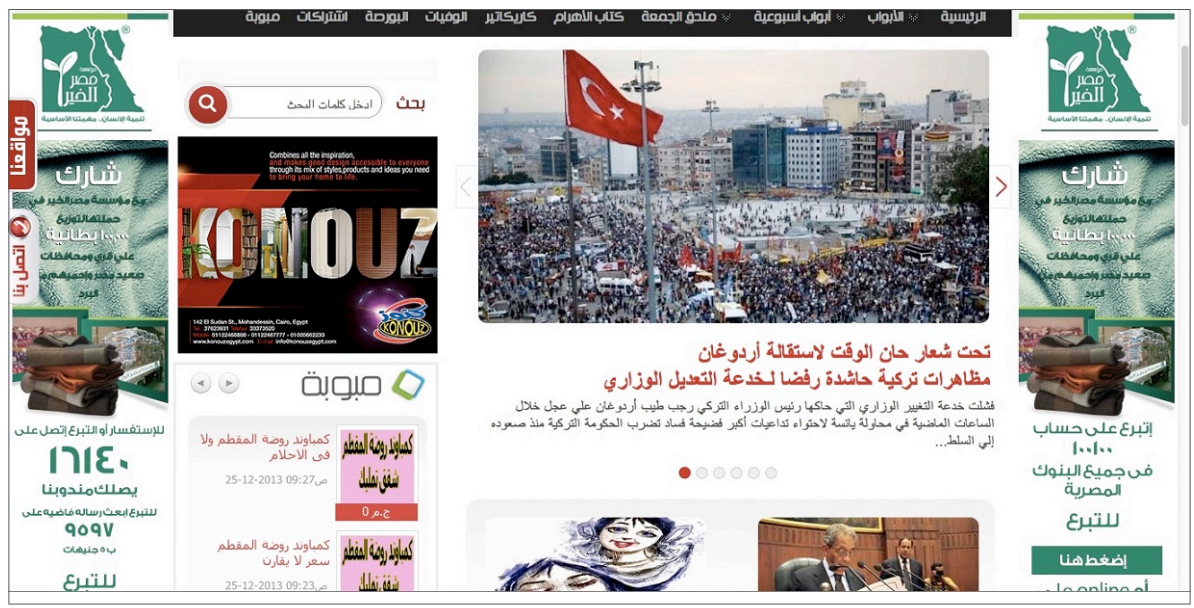

Fig. 1. Capa do jornal Al-Ahram em 27 de dezembro de 2013.

Fonte: Disponível em: <www.ahram.org.eg >. Acesso em: 27 dez. 2013.

A crise na Turquia já havia provocado o pedido de renúncia por parte de três ministros. A poucos meses das eleições no país, os filhos dos ministros, aliados ao governo, foram acusados de corrupção e favorecimento político. Erdogan, no poder há dez anos, foi avaliado como autoritário pela mídia internacional devido a ações para conter os fortes protestos durante junho de 2013, que reuniram mais de dois milhões de turcos nas ruas.

Não se trata, portanto, de uma notícia sobre a África, já que a Turquia é um país euro-asiático. A Wikipedia informa que o continente africano possui os povos mais pobres do mundo e nenhum de seus países é realmente desenvolvido. É o terceiro maior continente em extensão e o segundo em população, muito diversa étnica, cultural, social e politicamente.

Esse continente pode ter sido o berço da humanidade. O racismo institucionalizado e a fome marcam sua história. Sua geografia contrasta os desertos do interior com as florestas equatoriais das bordas. As divisões políticas da África foram estabelecidas artificialmente pelos países europeus, separando-a segundo seus interesses e desconsiderando os dos colonizados. Após a independência, a situação redundou em lutas separatistas, golpes de estado e ditaduras.

Apesar de a página inicial do site estar tomada de visualidades, destaca-se claramente o conteúdo fotojornalístico. Em nível icônico, temos uma praça tomada por pessoas. Distingue-se em primeiro plano a bandeira vermelha da Turquia e as figuras da lua crescente e da estrela em branco. O iconograma "manifestação pública" leva ao topos "história nacional que se faz com luta e protesto". Há outras bandeiras vermelhas espalhadas pelo espaço de representação da fotografia, redundando com aquela que está em primeiro plano. A manchete, também em vermelho, fala da exigência que o povo faz de renúncia do primeiro-ministro Erdogxan, sublinhando o que já havia sido apresentado pelo iconograma. 
Há uma demarcação política de território e a bandeira é bastante enfática a esse respeito.

Os eixos vertical e horizontal destacam-se fortemente na composição, apoiados nos elementos em forte relação ortogonal entre si (prédios, postes, bandeiras à revelia da extensão em planície do povo na rua). Essa configuração estética faz ressoar a ortogonalidade do espaço fotográfico e da condição topológica humana (DUBOIS, 1993, p. 212).

Se passarmos à poética desse espaço, a imensa praça fotografada de cima para baixo não fala da nossa pequenez diante do infinito e sim de um fervilhar cujo caos é equilibrado pelo desejo uníssono, explicado pelo título da imagem. Se a casa protege o sonhador (BACHELARD, 1993, p. 26), e se há reversibilidade do micro com o macrocosmo, a praça figura a casa de todo um povo que sonha a própria sociedade. Vemos que mesmo no nível fenotípico, e escancaradamente no nível arquetípico, a praça assume aqui a geografia do centro, uma estrutura arquetípica que impulsiona os cruzamentos e as tomadas de rumo.

A enorme bandeira turca ergue-se do povo em direção ao céu, lugar da plenitude e terço superior da foto, adonando-se do topo do espaço com pouca luz e sem nuvens. As pessoas são emolduradas pela cidade de prédios duros e acinzentados, garantindo sua unidade. Os edifícios contrastam sua pobreza imagética com os vermelhos ressonantes sustentados por punhos erguidos, reforçando pela redundância rítmica a mensagem da luta. Nas bandeiras levantadas há uma continuação da imagem simbólica das armas em punho, um isomorfismo que liga a verticalidade à transcendência e à virilidade (DURAND, 1997, p.161). Nesse sentido, a inscrição espacial desse acontecimento, por sua potência arquetípica, foge das fronteiras geográficas e fala à condição humana de sujeitos em todos os espaços nacionais: quaisquer lugares onde poderiam ser erguidas bandeiras, conquistadas mudanças, unificados cidadãos.

\section{América do Norte olha para a Ásia}

O mesmo nível arquetípico se manifesta e, pela intromissão de certa informação do nível entimemático, inibe-se, na fotografia publicada na capa do jornal mais popular da América do Norte, The New York Times, sediado nos EUA. É esse país que carrega no seu gentílico o nome de um continente inteiro. O Novo Mundo, no entanto, vai além dos EUA, dividindo-se entre América do Norte e do Sul. Uma se liga à outra pelo istmo do Panamá. Ainda que jovem, o continente abriga três das maiores economias do mundo: EUA, Canadá e Brasil.

A América do Norte é um subcontinente com apenas três países. México, Canadá e EUA compartilham as terras sobre as quais se distribuem cadeias de montanhas jovens, muitas com vulcões ainda em atividade e planícies na porção central do subcontinente, com grandes rios e lagos. Mas não é desse território que fala a foto de capa do New York Times, e sim da Ásia. A notícia foi a explosão de um carro-bomba em Beirute, capital do Líbano, ocorrido na manhã do dia 27, que matou, entre outros, o ex-ministro de Finanças Mohammed Shattah. 


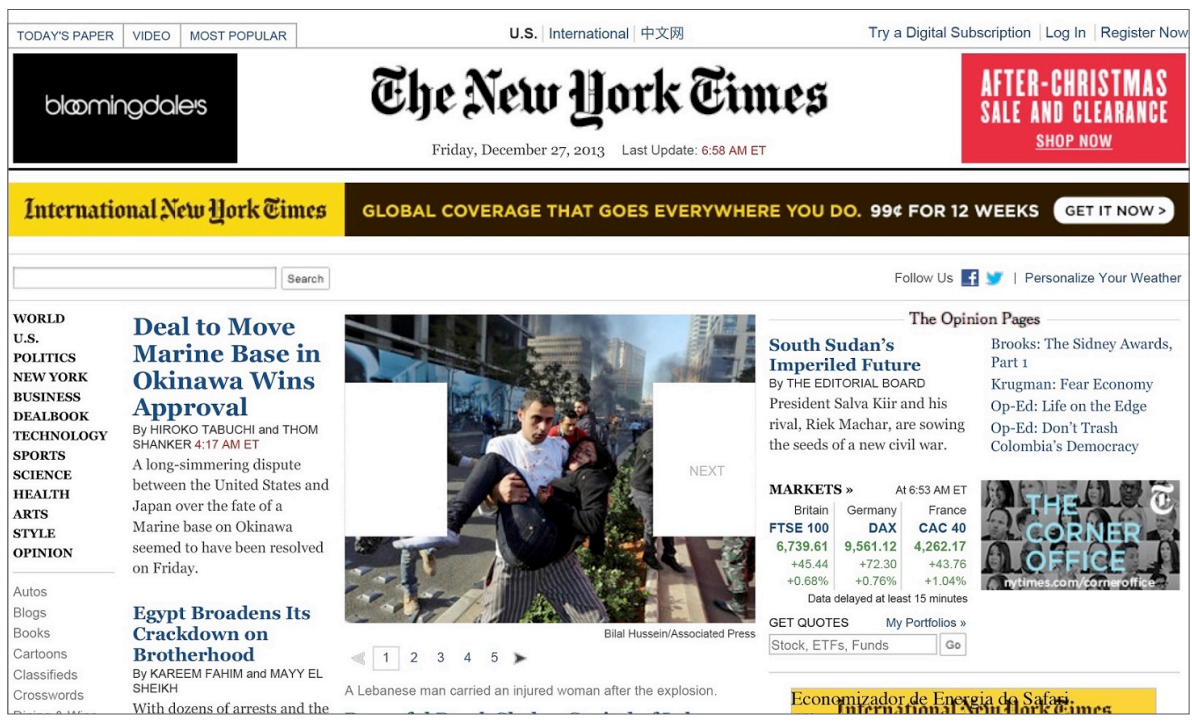

Fig. 2. Capa do jornal The New York Times em 27 de dezembro de 2013 Fonte: Disponível em: <www.nytimes.com>. Acesso em: 27 dez. 2013

O acontecimento diz respeito a um conflito histórico. Parte do território libanês foi ocupada militarmente pela Síria por quase três décadas e o economista morto era parte da oposição sunita libanesa ao presidente sírio xiita, Bashar al-Assad. Um dos primeiros grandes protestos no Oriente Médio na chamada Primavera Árabe, em janeiro de 2011, foi a reação dos sírios contra governo de Assad.

A fotografia está bem centralizada na página, como única disponível no campo de visão. Ela mostra um homem carregando uma mulher ferida em primeiro plano com fumaça ao fundo. Estão visíveis também algumas chamas e há outras pessoas feridas na cena. Iconicamente, é a dor que salta aos olhos, desenhada no semblante dos retratados, na paleta de cores azuladas e enegrecidas e na posição encurvada em que seus corpos foram paralisados no momento do clique. Mas o homem carregando a mulher ferida parece avançar na direção de quem olha a fotografia, como que pedindo passagem. Há um transbordamento do espaço de representação (da foto) sobre o espaço topológico (do espectador) com potencialidade para que o plano da representação se desloque do longínquo e ameace o próximo. ${ }^{4}$ É assim que o iconograma "dor" vem compor um topos eloquente, que diz: "isso poderia acontecer com você".

4 Dubois (1993) arrola quatro tipos de espaços na fotografia: o espaço referencial, no qual se efetua um corte para se produzir determinada fotografia; o espaço representado, que compreende a porção capturada pelo clique; o espaço de representação, dado pelos bordos da fotografia propriamente dita e dentro do qual se organizam as figuras capturadas, e o espaço topológico, que é onde se insere o espectador da fotografia, em geral num eixo ortogonal, com a expectativa de uma coerência entre esta ortogonalidade do corpo humano e a do espaço de representação. 
Se a fotografia é a inscrição da luz, nem a luz do sol, entrando na lateral da fotografia, ajuda a esclarecer os personagens, dando ao momento condições mais racionais de análise; pelo contrário, o sol frio do dia em que a fotografia foi tomada atua como elemento que corrobora o acontecimento do caos, luz incapaz de privá-lo de sua condição desoladora. O elemento capaz de ressignificar o caos da cena é a intimidade entre os personagens. A tradução iconográfica da fotografia tem continuidade com representações visuais clássicas da história da arte, como a Pietá de Michelangelo. A relação que se estabelece entre o homem e a mulher em seu colo faz uma atualização dos símbolos da intimidade, confundindo noções como a da morte e do repouso.

Aqui há um isomorfismo entre as imagens simbólicas do sepulcro e do berço (DURAND, 1997, p. 237), um aconchego amedrontador e apaziguante. Essa condição imagética traz à fotografia a potência arquetipológica, no sentido que permite ao homem sentir-se tocado e deslocar-se para um espaço, em nível fenomenológico, mais próximo ao do acontecimento. A fotografia convoca para a hermenêutica um sentido vivido ao mexer com a intimidade de quem vê, unindo-o à cena de modo humanamente cúmplice. Não se está mais aqui no território fenotípico das possibilidades claramente limitadas e sim no espaço arquetípico da cumplicidade humana.

No entanto, a legenda da fotografia reforça e diferencia o que o ícone já disse: "Homem libanês carrega mulher ferida após explosão". A legenda distancia no nível entimemático aquilo que o iconograma poderia aproximar, circunscrevendo a tragédia a um território longínquo. Por esforço da informação jornalística, a imagem simbólica arquetípica do espaço como lugar de cumplicidade acaba apaziguada - e, talvez, esterilizada - pela imagem simbólica estereotipada do território do bárbaro, longe de nós, não o nosso.

\section{América do Sul olha para si mesma}

De uma complexa simbolização em que um espaço compartilhado se distancia e se degrada em território barbarizado, passamos a uma imagem que, de tão pouco pregnante, não fala de lugar algum. Trata-se da fotografia publicada na capa do jornal mais popular da América do Sul, O Globo, sediado no Brasil. 


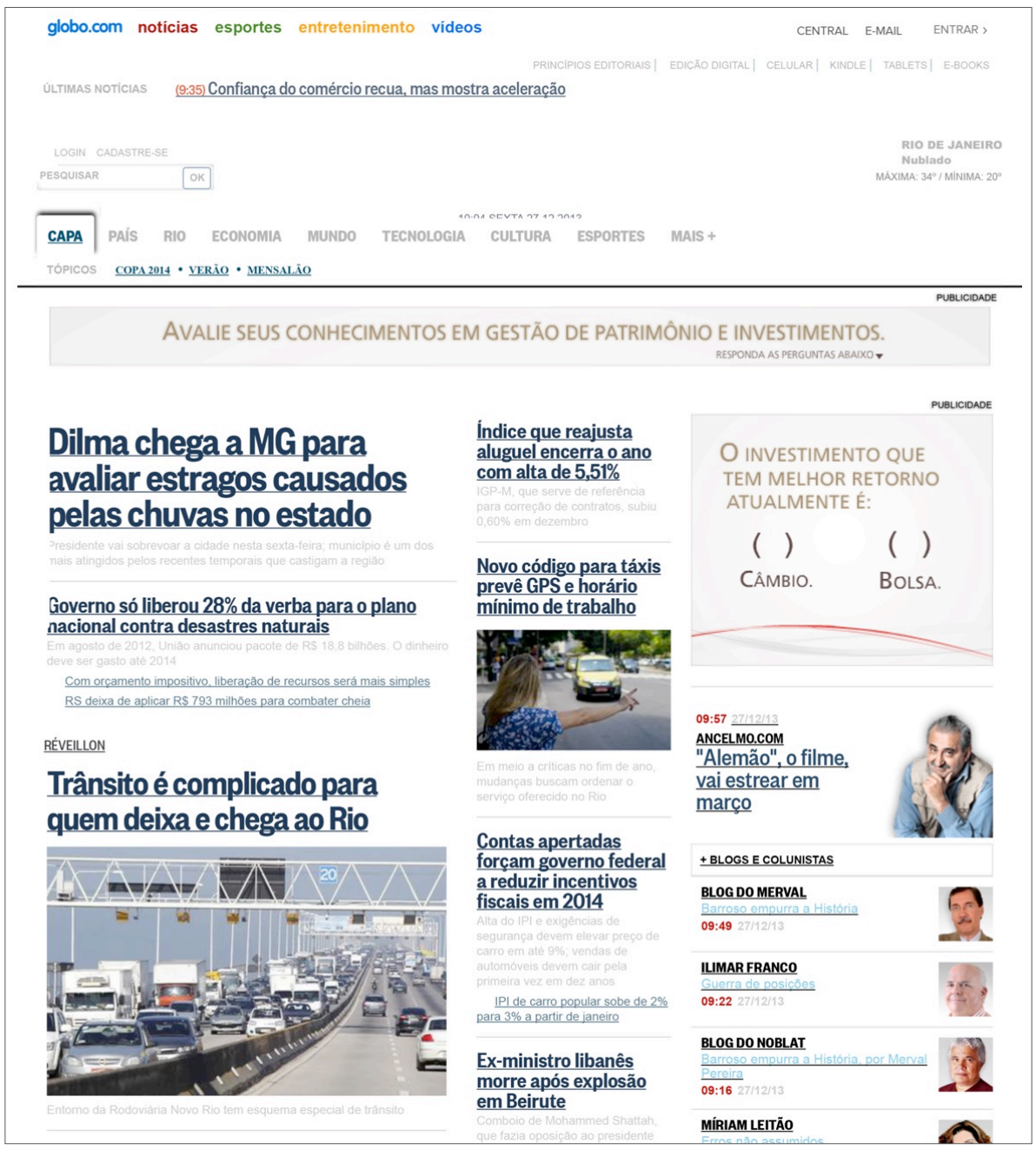

Fig.3. Capa do jornal O Globo em 27 de dezembro de2013. Fonte: Disponível em <www.oglobo.globo.com>. 27 dez. 2013.

A América do Sul também é um subcontinente compreendendo a porção meridional americana. A par das altas montanhas da cordilheira dos Andes, a oeste, tem planaltos suaves no leste, e planícies grandes no sul. O nordeste é ocupado pela bacia Amazônica, imensa e plana. Essa paisagem rica, biodiversa, não é retratada no jornal e sim a paisagem urbana e anônima.

A capa de $O$ Globo apresenta muitos ícones, com publicidade e retratos de colunistas ocupando toda a coluna à direita. A notícia que foi ilustrada com a foto maior é sobre os engarrafamentos nas autoestradas que saem da cidade do Rio de Janeiro. 
Trata-se de uma fotografia sem nenhum atrativo especial em sua composição, mostrando as pistas das duas mãos de trânsito, a da esquerda completamente tomada por veículos. Percebe-se uma autoestrada devido às numerosas pistas de rolagem de ambos os lados e a separação das mãos por uma mureta de concreto. A presença de numerosos postes de iluminação e de treliças metálicas indica o território como zona urbana. A outra foto presente no site também se apresenta inscrita no urbano, pela quase onipresença do asfalto. O iconograma ao qual leva o ícone é "trânsito intenso".

A legenda da fotografia fala de um esquema especial de trânsito que teria sido montado na cidade. No nível entimemático é possível avançar para a circunscrição mais exata do território em que ocorre a cena. A paisagem é árida, feita toda de concreto e ocupada apenas por veículos - seus motoristas e tripulantes não são visíveis na foto. Um topos marcadamente urbano se configura: "trânsito intenso nas rodovias próximas às metrópoles". Não há topos digno de nota, os sentidos figurados estão ausentes. O território aqui é seco, desprovido de graça, retratado de um ponto de vista sobejamente conhecido dos prováveis leitores.

Permanece-se num espaço doméstico, embora, pela extrema generalização icônica (não há elementos contextuais que indiquem tempo ou localização mais precisos), essa representação possa ser tomada como a de qualquer outra metrópole mundial. O espaço arquetipal não se evoca. Nem o marcado espaço topológico tem força suficiente para despertar alguma imagem simbólica. A fotografia está incapacitada de estabelecer relação com o espaço arquetípico dado que a poética do espaço é uma condição relacional entre imaginação e matéria (WUNENBURGER, 2007, p. 37).

\section{Ásia olha para si mesma}

A Ásia é o maior dos continentes, tem as montanhas mais altas e os rios mais extensos. Suas florestas são as mais densas, seus desertos os maiores, seus idiomas os mais diversificados. É uma terra de superlativos, que declinou ao longo do século XVI enquanto a Europa florescia. O continente é marcado por guerras constantes entre grupos políticos opositores.

A foto em destaque no dia da coleta dos dados no The People's Daily, sediado na capital chinesa Pequim, mostra uma ilha encimada por uma nuvem de fumaça branca que sai de seu centro. A legenda informa sobre o aparecimento de uma ilha, por consequência de erupção vulcânica, que pode unir-se à ilha próxima. Essa legenda é fundamental para a organização do entimema "ilhas do Pacífico são vulcânicas".

Essas informações são suficientes para decodificar um território que emerge fenomenicamente da imagem, mas temos aqui um grau a mais de simbolização que avança decididamente sobre o espaço arquetipal: o oceano, com sua imensidão maternalmente aquosa, entra em tensão com o fogo, que pode mesmo ser violento, pois se alça acima 
das águas. A coincidentia oppositorum desses dois elementos é capaz de ativar o nível arquetipológico da imagem simbólica.

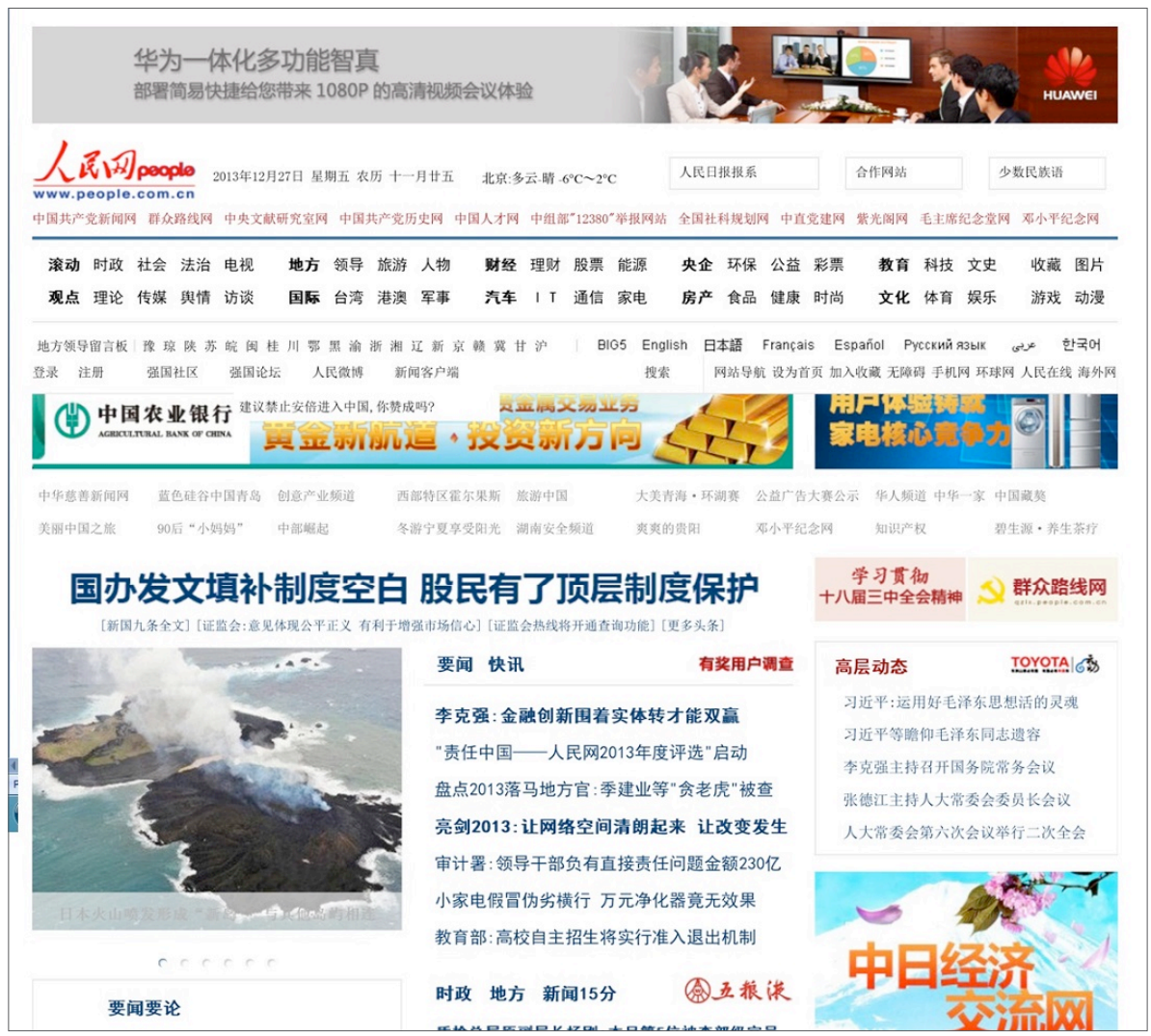

Fig.4. Capa do jornal The People's Daily em 27 de dezembro de 2013.

Fonte: Disponível em: <www.people.com.cn>. Acesso em 27 dez. 2013.

A água e o fogo juntam-se à imensidão do espaço, e esse sentimento, natural diante do mar, é acentuado pela perspectiva plongé da fotografia aérea. A presença dos elementos materiais atua com grande força dentro do espaço representado, pois se torna um desafio não ceder à força atrativa da imagem da grandeza geográfica quando toda uma ilha inteira cabe dentro da fotografia. Esse olhar uraniano possibilita-nos planar sobre os acontecimentos e melhor discerni-los. No entanto, aqui, somos convidados a uma visão contemplativa, deixando para a terra o protagonismo da ação. A foto sugere um apaziguamento em que o magma vem à superfície para se encontrar com o oceano. O espaço criado pela fotografia cria condições para a inscrição dos sujeitos em um nível identitário de humanidade, superando a fronteiriça identidade nacional. Ao contrário 
do que acontece no jornal brasileiro, ainda que a legenda delimite o território, não é ele que prevalece, e sim a imagem simbólica de um espaço cósmico que se impõe.

\section{Europa olha para a América do Norte}

Enquanto na fotografia asiática há a ativação do nível arquetipal da imagem em função de seu espaço referencial, no mais popular jornal europeu, esse mesmo nível se dilui em função da desvalorização gráfica da fotografia colocada em concorrência assimétrica com outra.

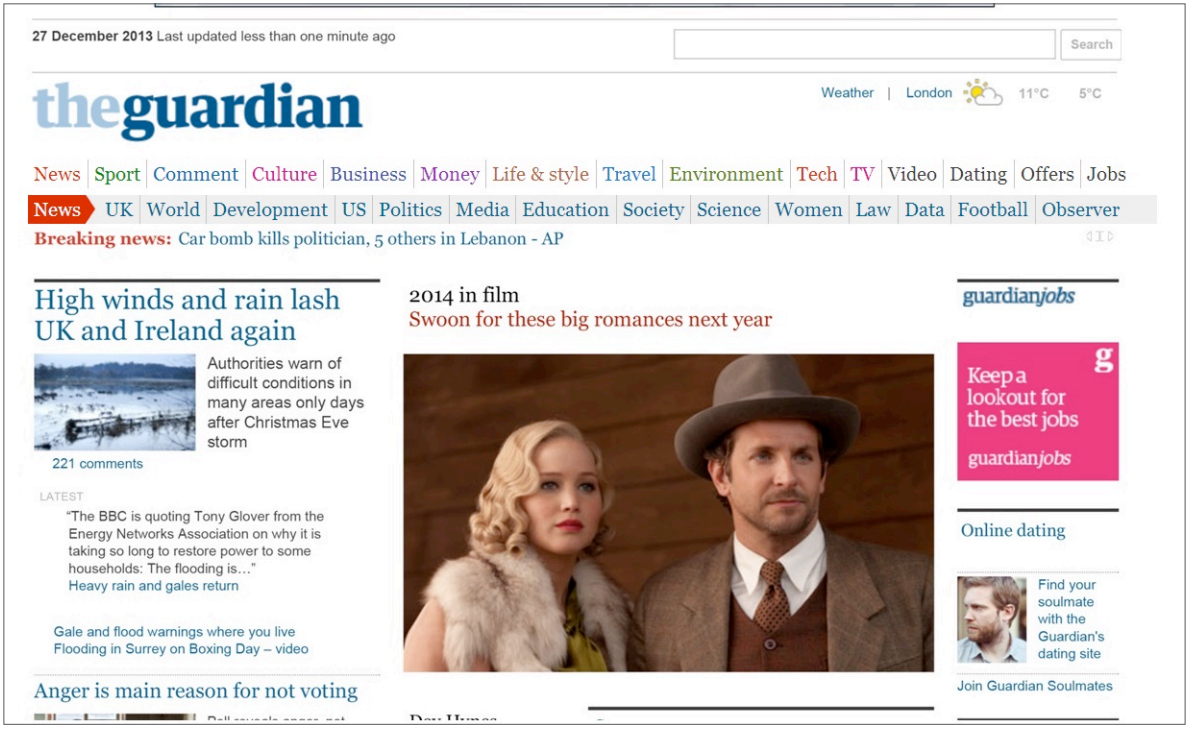

Fig.5. Capa do jornal The Guardian em 27 de dezembro de 2013.

Fonte: Disponível em <www.guardian.co.uk>. Acesso em: 27 dez. 2013.

A Europa é o segundo menor continente em extensão, mas sua população é a terceira maior. Se em 1900 ela abrigava um quarto da população mundial, hoje abriga apenas $11 \%$. A Europa é o berço da cultura ocidental e, do século XVI ao XX, controlou cultural e politicamente grande parte do mundo. A partir desse continente, desenrolaram-se as duas guerras mundiais, as quais trouxeram também o declínio de seu domínio, cedendo espaço para o protagonismo da União Soviética e dos EUA.

No século XIX, milhões de pobres deixaram a Europa rumando para América e Oceania. Por outro lado, da metade do século XX para nossos dias, a Europa tem recebido milhares de imigrantes vindos de países mais pobres, a ponto de representarem $85 \%$ do crescimento de sua população em 2005.

Essa complexidade de povos e territórios não se estampa no fotojornalismo do The Guardian. Salta aos olhos uma foto grande, colorida e nítida de um casal jovem 
vestido e penteado de acordo com costumes do início do século passado. Os atores Jennifer Lawrence e Bradley Cooper olham para um ponto situado fora do espaço de representação. O letreiro acima da foto indica que se trata de filme a ser lançado no próximo ano, informação que reforça o que a leitura iconográfica já havia indicado. A foto diz, no nível iconográfico, "casais do cinema são belos".

O território aqui precisa ser encontrado através do sistema de referências fornecido pelas roupas e pelo biótipo (brancos, loiros, olhos claros): Europa ou América do Norte. O filme é norte-americano, mas isso não é informado. Não há abertura em que se possa imiscuir um espaço arquetipal até pela ausência de contradições - como bem diz Bachelard (1993, p.67), é o apelo dos contrários que dinamiza os arquétipos.

À esquerda na mesma página, numa localização sobre a qual nosso olhar não recai a não ser num segundo momento, uma diminuta fotografia mostra uma paisagem em que predominam os tons branco e azul acinzentado, puxando para o metálico. Distinguemse os elementos referenciais: água de enchente, melhor identificável por causa da cerca cheia de vegetação presa que deve ter sido retida ali quando a água estava ainda mais alta. O título sobre a foto diz: "Ventos fortes e chuva castigam Reino Unido e Irlanda novamente". O pequeno texto ao lado da foto diz: "Autoridades alertam para as condições difíceis em muitas áreas apenas alguns dias após a tempestade da véspera de Natal".

Não só pela circunscrição das condições climáticas, mas pelo tamanho da fotografia, esse território se distancia consideravelmente do espaço arquetipal porque desconvida ao envolvimento. Uma imagem que não é vivida não poderá ser simbólica, assim, não mobilizará a ação que está na base de todo imaginário pregnante.

\section{Oceania olha para si mesma}

A Oceania, o Novíssimo Mundo, é o menor continente em área e em população, perdendo apenas para a Antártida. A Austrália tem montanhas modestas, a Nova Zelândia é formada por planícies extensas e nas ilhas, a maioria de origem vulcânica, o solo é arenoso, com pouquíssima vegetação, mas em algumas encontra-se uma floresta equatorial densa. Todas as ilhas da Oceania são majoritariamente ocupadas por indígenas, à exceção das duas maiores, Austrália e Nova Zelândia, habitadas predominantemente por descendentes de europeus britânicos que lá chegaram no século XVIII, lutaram contra os nativos e reduziram as populações a menos de 10\% do tamanho original.

Lá, o jornal mais popular é o The Sydney Morning Herald, sediado na Austrália. Sua capa costuma trazer quatro fotos acima das três colunas de conteúdo. A notícia que pode ser considerada manchete de capa (pelo letreiro em maior dimensão) traz uma foto menor do que todas as outras. 


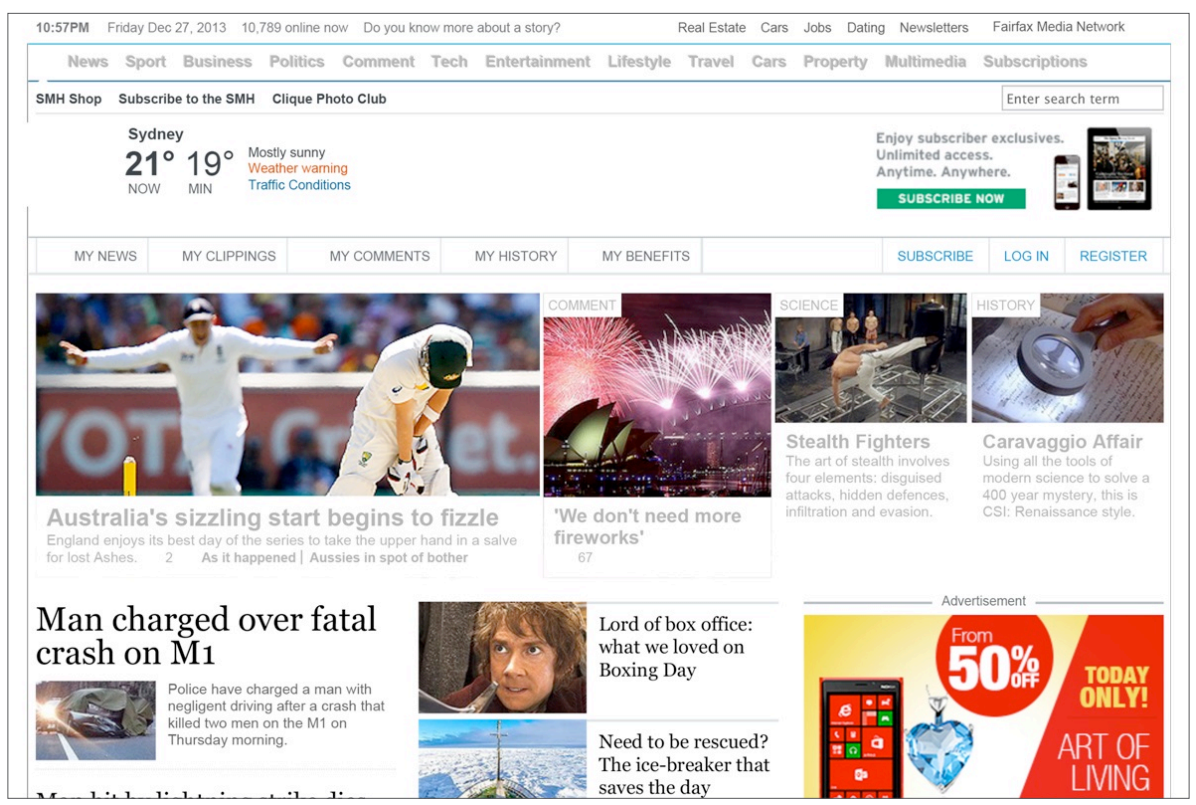

Fig. 6. Capa do jornal The Sydney Morning Herald em 27 de dezembro de 2013. Fonte: Disponível em: <www.smh.com.au>. Acesso em: 27 dez. 2013.

A principal manchete diz: "Homem acusado por acidente fatal na M1". A foto mostra um carro acidentado coberto por uma lona. A luz do farol aceso de outro veículo se destaca ao fundo. Em primeiro plano, uma porção do asfalto com a linha branca da marcação da pista. No último plano, o rochedo escavado para se abrir a autoestrada, mas praticamente indistinguível por causa da pequena dimensão da foto. A foto diz "acidente" e o pequeno texto ao lado, chamando para a reportagem completa, acrescenta: "A polícia acusou um homem de condução negligente após um acidente fatal que matou dois homens na M1 na quinta-feira de manhã". O território é ao mesmo tempo demarcado de modo preciso e impreciso - a M1.

Essa indicação é tão pobre em imagens que se torna simbolicamente ineficaz, não contém elemento capaz de provocar a imagem vivida. Assim como no caso da foto da América do Sul, é um território burocrático demais para ser o território de alguém. Poderia se tratar de qualquer lugar e por isso mesmo se trata de lugar nenhum, numa dessimbolização característica da pós-imagem (BARROS, 2013).

\section{Considerações finais}

Diz-se que estamos na era das imagens, opinião corroborada pela multiplicação exponencial de fotografias e vídeos disponíveis na contemporaneidade, facilitada pelas 
tecnologias de comunicação. No entanto, e provavelmente por isso mesmo, parece a cada dia mais difícil encontrar uma imagem com eficácia simbólica, entendida aqui como a potencialidade que uma imagem tem de promover perturbações a ponto de abrir caminho, no mínimo, para a sensibilização relativa aos assuntos reportados, no caso do fotojornalismo, e, no máximo, para uma transformação do eu profundo e da sociedade. Parece faltar eficácia simbólica para mobilizar não só conteúdos fenomênicos, ligados às coerções culturais e históricas de um tempo e de um espaço dados, mas também os arquetípicos, que projetam o homem no tempo mítico, que é estável e, paradoxalmente, real promotor de mudanças.

No caso do fotojornalismo on-line, diferentemente do impresso, não há o costume de utilizar uma grande foto na capa, e sim várias pequenas fotos, como se a atenção do leitor devesse ser disputada pelo maior número possível de chamariscos. Em contrapartida, o fotojornalismo profundo, que alia técnica com estética, é empurrado para seções especializadas, procuradas talvez somente pelos que também são especialistas.

Verificamos que a manifestação de um imaginário territorial não é necessariamente portada pelo suposto dono do território. A imprensa da África e da América do Norte voltou sua atenção a notícias da Ásia. A Europa falou sobre a América do Norte. Ásia, Oceania e América do Sul falaram de si mesmas, mas com profundas diferenças na abordagem. Enquanto a imprensa asiática deixa aflorar na fotografia em destaque um imaginário até certo ponto pregnante, a sul-americana e a da Oceania não ultrapassaram o nível do código puro e simples, da informação desencarnada e, por isso mesmo, com pouco sentido.

Nesses dois casos, nem espaço nem território compareceram na fotografia. A imprensa europeia, por sua vez, colocou o destaque principal sobre a América do Norte, embora dividido com uma questão local - a questão de seu próprio território - que enfrentava problemas climáticos na época da coleta do corpus, não valeu imagem em destaque, o que se averigua com o diminuto tamanho da foto que se incumbe da tarefa de dar a desagradável e monótona notícia local. A África não foi olhada de modo algum, nem por si mesma.

Não nos parece possível falar, a partir dessas fotos, de uma homogeneização cultural. A maior parte dessa imprensa tida como a mais popular de seus continentes, devido ao número de acessos on-line, volta sua atenção para assuntos de outros continentes que Ihe interessam política ou culturalmente, exceção feita à América do Sul e à Oceania que, coincidência ou não, são respectivamente o novo e o novíssimo mundo. Essa amostragem pequena e aleatória dá pistas, sim, de uma agenda mundial focada na Ásia e silenciosa sobre a velha África - silêncio mais preocupante ainda porque o próprio continente africano silencia-se sobre si mesmo.

As diferenças entre as várias partes do mundo parecem pasteurizadas, mas não por iniciativa das culturas locais, preocupadas em construir uma identidade própria, que supere localismos e que fale de uma unidade nacional ou mesmo continental, e sim por efeito de dispositivos jornalísticos, como o critério de noticiabilidade e o valor-notícia. 
É talvez preocupante - mas não surpreendente - que o jornalismo tenha atingido tal grau de indiferenciação no Oriente e no Ocidente e que esse valor permaneça e talvez mesmo se aprofunde na mídia on-line.

Se em nível arquetipológico do imaginário é esperada certa universalidade que funcione como matriz dinâmica da função fantástica, o contrário deveria ocorrer no nível fenomenológico, no qual a encarnação de símbolos em diferentes culturas, histórias, contextos resultaria numa profusão de imagens que teriam na sua diferenciação fenotípica a compensação de seu esvaziamento simbólico causado pela baixa plurivocidade.

A fotografia tem a peculiaridade de, possuindo apenas duas dimensões, representar a terceira por meio da ilusão de perspectiva. A coerção técnica da fotografia é alta o bastante para explicar a repetição de suas representações. Adicione-se a isso a premissa de Sontag (2004, p. 96) de que fotografia é tema. A teoria literária e a mitologia já nos preveniram sobre a existência de bem poucos temas para serem narrados, sendo o jeito de narrar que vai se multiplicar. Ora, isso coloca a fotografia num beco sem saída, pois se a única salvação para a criatividade na fotografia é o jeito de fazê-la, mas o jeito de fazê-la é limitado por sua coerção técnica - tudo já está programado dentro da caixa-preta, avisa Flusser (2002) -, onde residirá, então, a força de resistência da fotografia?

No interesse humano. Continuaremos a nos interessar pela fotografia enquanto ela nos servir de espelho reflexivo ou projetivo. E o espelho mais interessante não é aquele que mostra o que já sabemos de nós ou o que desejamos mostrar, e sim o que mostra aquilo que em nós parece oculto ou aquilo em que podemos nos transformar.

Por isso, pode-se vaticinar a baixa expectativa de vida dos selfies. A exploração do autorretrato - tornado tão banal pela tecnologia que instalou uma câmera no aparelho de telefone celular voltada para o próprio usuário - há de chegar logo à saturação porque as melhores imagens de nós não estão em nós mesmos e sim no outro. Isso parece ser verdade mesmo numa dimensão macro; pois, sim, há motivos para a imprensa de um lugar noticiar o que ocorre no outro: o desenrolar de um fato alhures pode afetar os interesses locais. No entanto, concorrendo com ou sublinhando essa injunção política está o interesse pelo outro, ainda que eivado de curiosidade por si mesmo.

A aproximação mágica através da fotografia até pode ser dada codificadamente por um tropos qualquer, como quer Eco (1976). Mas uma fotografia realmente fala a um homem por causa de sua capacidade de fazê-lo perceber que seu pequeno mundo é, na verdade, o grande mundo; que o que fala do macrocosmo também fala de si. É essa oportunidade comunicativa que o fotojornalismo parece estar perdendo em nome da ânsia em multiplicar estímulos com a esperança de que algum encontre ressonância. 
Université de Lyon 3, doutora em Ciências da Comunicação pela ECA/USP.

anataismartins@hotmail.com

Anelise Angeli De Carli é jornalista, mestranda do Programa de Pós-Graduação em Comunicação e Informação da UFRGS.

anelisedecarli@gmail.com

\section{Referências}

BACHELARD, G. A poética do espaço. São Paulo: Martins Fontes, 1993.

BARROS, A. T. M. P. Símbolos do inferno: imagens de lugar nenhum e de algum lugar. Discursos Fotográficos, Londrina, v.9, n. 14, p. 99-122, jan-jun 2013. Disponível em: <http://www.uel.br/ revistas/uel/index.php/discursosfotograficos/article/viewFile/13255/12412>. Acesso em: 29 dez. 2013.

DUBOIS, P. O ato fotográfico. Campinas: Papirus, 1993.

DURAND, G. As estruturas antropológicas do imaginário: introdução à arquetipologia geral. São Paulo: Martins Fontes, 1997.

ECO, U. A estrutura ausente. São Paulo: Perspectiva, 1976.

FLUSSER, V. Filosofia da caixa preta. Ensaios para uma futura filosofia da fotografia. Rio de Janeiro: Relume Dumará, 2002.

SANTOS, M. Por outra globalização. Do pensamento único à consciência universal. Rio de Janeiro: Record, 2003.

SONTAG, S. Sobre fotografia. São Paulo: Companhia das Letras, 2004.

THOMAS, J. Introduction. IN: Introduction aux méthologies de l'imaginaire. Paris: Ellipses, 1998. p. $16-21$.

WIKIPEDIA. Disponível em: <http://pt.wikipedia.org>. Acesso em: 17 dez. 2013.

WUNENBURGER, J-J. La vie des images. Grenoble: PUG, 2002.

O imaginário. São Paulo: Edições Loyola, 2007. 